\title{
Seasonal variation in $\mathrm{C}, \mathrm{N}$ and $\mathrm{P}$ budgets and tissue composition of the mussel Mytilus edulis
}

\author{
A. C. Smaal*, A. P. M. A. Vonck \\ National Institute for Coastal and Marine Management/RIKZ, PO Box 8039, 4330 EA Middelburg, The Netherlands
}

\begin{abstract}
Net $\mathrm{C}, \mathrm{N}$ and $\mathrm{P}$ budgets of mussels were measured monthly in a field laboratory for a year The calculated scope for growth was compared with the observed growth rates per month, for each element. Assuming ambient food, scope for growth was calculated and compared with changes in the tissue composition of mussels from an estuarine field population. When total organic material was used as food, the calculated scope for growth overestimated the actual growth rates throughout the year. When phytoplankton was considered to be the main food source, the scope for growth provided by each element compared well with observed changes in tissue content, except during the spawning period. During spawning, the difference between growth and scope for growth indicated a considerable loss of $\mathrm{C}, \mathrm{N}$ and $\mathrm{P}$. These losses exceeded estimated loss through gametes, indicating additional loss, ascribed to tissue damage. Good correspondence was found between the predicted and observed C:N:P stoichiometry of mussels. Compared with phytoplankton, mussels contained relatively more $N$. The absorption efficiencies of $\mathrm{C}, \mathrm{N}$ and $\mathrm{P}$ were not significantly different, but in most cases the excretion ratios of $C: N$ and $N: P$ showed that $N$ accumulated more than $C$ and $P$. Average annual net growth efficiency was higher for $\mathrm{P}$ than for $\mathrm{C}$ and $\mathrm{N}$. Elemental residence time in tissue, however, was highest for $N$. It is concluded that mussels are able to use $N$ more efficiently than $C$ and $P$, because they retain it better.
\end{abstract}

KEY WORDS: Excretion - Feeding · Gametogenesis - Growth · Metabolic requirements · Nutrient turnover $\cdot$ Scope for growth

\section{INTRODUCTION}

Bivalve molluscs in many areas have been found to show seasonal changes in body weight and biochemical composition (Dare \& Edwards 1975, Bayne \& Widdows 1978, Pieters et al. 1980, Rodhouse et al. 1984a, Hawkins et al. 1985). These changes reflect the fluctuations in food supply and demand (Cadée 1982, Berg \& Newell 1986, Smaal \& Haas in press), and raise the question of how the mussel regulates food acquisition optimally in relation to metabolic requirements (see Hawkins \& Bayne 1992 for review). Mussels show adaptive responses to variable food quantity and quality. They regulate filtration, ingestion and absorption by preferential uptake of edible material, adjust-

\footnotetext{
-Present address: Netherlands Institute for Fishery Research/ RIVO-OLO, PO Box 77, 4400 AB Yerseke, The Netherlands. E-mail: smaal@rikz.rws.minvenw.nl
}

ment of gut content and gut-passage time, and resorption of metabolic faecal losses (Hawkins \& Bayne 1992, Hawkins et al. 1996).

The seasonality of the mussel's metabolic requirements is dominated by its gametogenic cycle, which in many areas shows a typical seasonal pattern: a spawning period in spring and summer; a period of germinal quiescence and glycogen storage; followed by a period of gonad development in late autumn and winter (Gabbott 1983). During periods when food intake exceeds metabolic requirements and spawning loss, body and shell size increase. Glycogen is used as an energy source during the quiescent and early stages of gametogenesis, but in later stages it is conserved, possibly to be used in the lipid storage cycle, and protein serves as the major energy source (Bayne et al. 1982). By coupling the biochemical composition and the physiological energetics of the animals, Hawkins et al. (1985) showed that metabolic requirements were met 
from internal sources when food was scarce. They found low absorption efficiencies during these periods, and inferred that mussels maximize energy acquisition in a time-averaged manner rather than instantaneously. Hawkins \& Bayne (1985) also demonstrated the utilization of protein for catabolism, plus increased protein turnover, and a higher net growth efficiency for nitrogen than for carbon (see also Hawkins 1985). They concluded that a mussel population feeding mainly upon phytoplankton was more likely to have been limited by utilizable carbon than by nitrogen. The findings of Grant \& Cranford (1991) are relevant here. They compared net carbon and nitrogen budgets of Placopecten magellanicus, expressed as scope for growth, with observed growth, and showed that carbon-based scope for growth measurements overestimated actual growth under nitrogen-limited conditions. (The latter seemed to be the case with kelp as food). Hatcher (1994) described turnover of nitrogen $(\mathrm{N})$ and phosphorus $(\mathrm{P})$ in various benthic invertebrate species, observing that $\mathrm{P}$ turnover exceeded $\mathrm{N}$ turnover, and that $\mathrm{P}$ metabolism showed less physiological plasticity than $\mathrm{N}$ metabolism. Hatcher suggested that a relatively high availability of $\mathrm{P}$ in the diet was required for this, and recommended measuring C:P or N:P ratios rather than $\mathrm{C}: \mathrm{N}$ ratios when evaluating potential food.

In the study described here, net $\mathrm{C}, \mathrm{N}$ and $\mathrm{P}$ budgets of mussels of $5 \mathrm{~cm}$ long were measured monthly under semi-field conditions in a field laboratory for a year. We compared calculated scope for growth per element with observed growth rates per month. Net growth efficiencies, turnover and budget stoichiometry were analysed, in order to evaluate the relative importance of the various elements, and to ascertain (1) whether
$\mathrm{C}, \mathrm{N}$ or $\mathrm{P}$ are factors limiting the food available to the mussels throughout the year, considering the seasonality in metabolic requirements, and (2) how retention of a limiting element is regulated throughout the year.

\section{MATERIAL AND METHODS}

Experimental conditions. Physiological rates (clearance, absorption, respiration, excretion) were measured monthly in the period May 1988 to April 1989, except for December 1988, in a field laboratory at the mouth of the Oosterschelde (Fig. 1), an unpolluted estuary in the southwest of the Netherlands (Nienhuis \& Smaal 1994). For each series of measurements, animals were sampled from the field and prepared for measurements in the field laboratory. Each month, 50 of the sampled mussels were kept in raceway systems, so that in the second week of the monthly period their physiological rates could be determined. New animals were taken from the field for the next series of measurements. The field laboratory was continuously supplied with natural seawater with a salinity ranging from 29 to $32, \mathrm{pH}$ from 7 to 8 and an $\mathrm{O}_{2}$ saturation ranging from 80 to $120 \%$ throughout the year.

Animals. Each month, 100 mussels Mytilus edulis L. about $50 \mathrm{~mm}$ long were collected from the Oosterschelde estuary (Fig. 1) at low tide and cleaned of epibionts. Directly after sampling, their length was measured to the nearest $0.5 \mathrm{~mm}$. A subsample of 50 mussels was used for measuring biomass, $\mathrm{C}, \mathrm{N}$ and $\mathrm{P}$ content and gonad development stages (see below); the other 50 individuals were kept in raceway systems, and 14 of them were used for physiological measure-

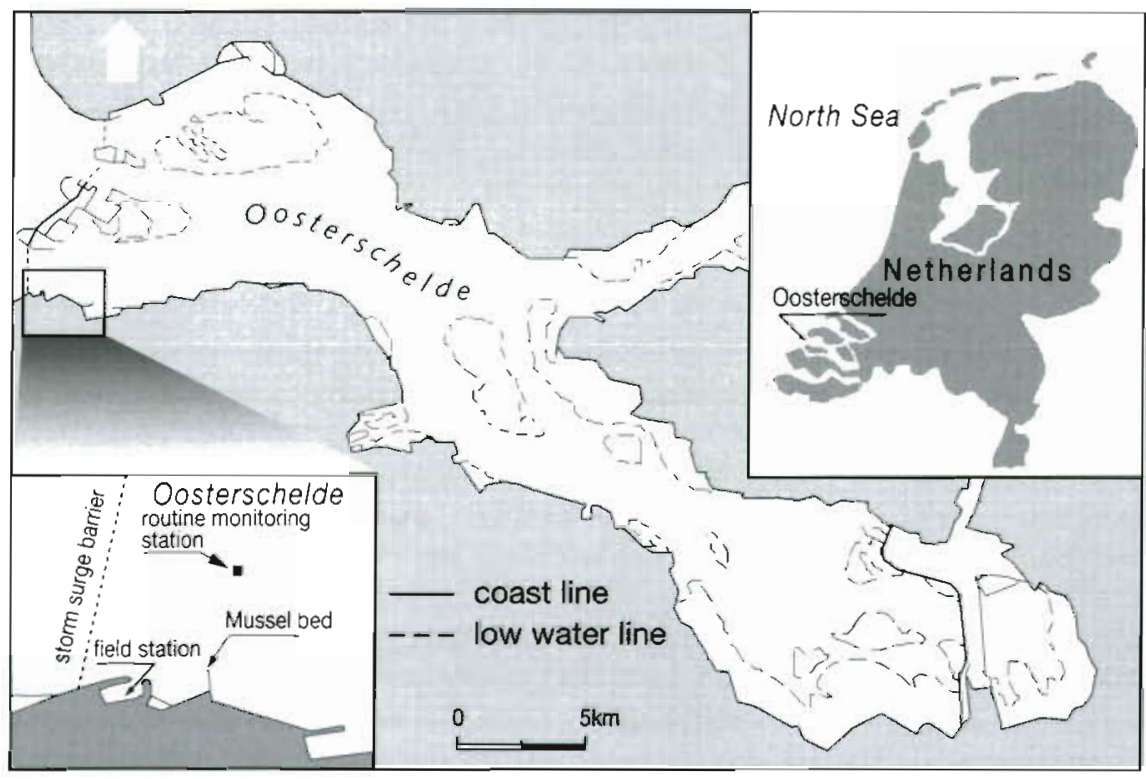

Fig. 1. The Oosterschelde estuary, showing field laboratory, mussel sampling site and routine seston monitoring station 
ments (see next section). After 1 mo, the biomass, gonad development stages and $\mathrm{C}, \mathrm{N}$ and $\mathrm{P}$ content of the remaining mussels were determined.

The shells were included when measuring biomass (Total Wet Weight, TWW). The tissues and shells of 15 of the initial monthly subsample of 50 mussels were separated and dried for $48 \mathrm{~h}$ at $70^{\circ} \mathrm{C}$ (Dry Flesh Weight, DFW; Dry Shell Weight, DSW), and ashed for $4 \mathrm{~h}$ at $450^{\circ} \mathrm{C}$. The difference between dry and ash weights gives ash-free dry weight of flesh and shell, expressed as Ash Free Dry Weight (AFDW) and Organic Shell Weight (OSW), respectively.

The gonad index was determined by microscopically examining the mantle tissue of 15 mussels, which was removed directly after sampling, stored in liquid nitrogen and sectioned at $10 \mu \mathrm{m}$, stained (Papanicolau) and stored in histoclear. Gonads were classified according to their degree of development and gamete density into 6 consecutive stages, with $0=$ resting phase, $1,2,3,4$ = various developing stages, 5 = gonad full of ripe gametes (Seed \& Brown 1977). The general reproductive state of these mussels was assessed by calculating a mean gonad index. An increase of the index indicates reproductive development, while a falling index suggests that spawning is in progress (Seed \& Brown 1977).

Tissue from the remaining 10 mussels was freezedried and homogenized for $\mathrm{C}, \mathrm{N}$ and $\mathrm{P}$ determinations. To analyse for $\mathrm{C}$ and $\mathrm{N}$, a subsample of tissue was measured with a Carlo-Erba elemental analyser. To analyse for $\mathrm{P}$, a subsample was treated with persulphate and the resulting $\mathrm{PO}_{4}$ was measured by autoanalyser colorimetry (Grasshoff et al. 1983).

To analyse for glycogen, tissue from 10 mussels was homogenized, treated with sodium hydrogenate and ethanol, centrifuged, dissolved in sulphuric acid and analysed as glucose at $\mathrm{pH}=7$ (Bergmeyer 1966).

Physiological measurements. Measurements were performed on individual mussels in grazing and respiration chambers. Sixteen grazing chambers were used to measure filtration, absorption, respiration and excretion rates. Fourteen of these contained one individual, each on a small platform. The 2 empty chambers served as a control. The volume of the chambers was $350 \mathrm{ml}$. The flow was adjusted so that the maximum reduction of particle concentration was $30 \%$ in the outflow. Filtration rate was measured as clearance rate (volume swept clear per h) by collecting composite samples of the inflow and outflow over a period of $2 \mathrm{~h}$, and then analysing subsamples for particle concentration by Coulter Counter ID. Absorption efficiency was measured by collecting the faeces produced during and after the clearance rate measurements. Care was taken to avoid collecting the pseudofaeces occasionally produced. Subsamples of the seston inflow were taken; faeces and seston were analysed for $\mathrm{C}, \mathrm{N}$ and $\mathrm{P}$ (see below).

Respiration and excretion rates were measured after the clearance rate measurements, for a period of 2 to $3 \mathrm{~h}$. The chambers were cleaned, filled with oxygensaturated seawater and sealed. The oxygen concentration was recorded with Yellow Springs laboratory polarographic electrodes, in order to check for a linear decline. Initial and final oxygen concentrations were determined by Winkler titration. The latter technique was also used to calibrate the probes. Subsamples were analysed for $\mathrm{NH}_{4}$ and for $\mathrm{PO}_{4}$ concentration by auto-analyser colorimetry. For May and June 1988 we used data on $\mathrm{PO}_{4}$ excretion from a previous experiment, reported by Prins \& Smaal (1994).

Seston analysis. Total suspended particulate matter (SPM), particulate organic carbon (POC), nitrogen (PON), phosphorus (POP) and chlorophyll a were measured as follows: SPM was measured after filtering 11 seawater over pre-ashed and weighed $1.2 \mu \mathrm{m}$ Whatman GF/C filters, drying for $24 \mathrm{~h}$ at $70^{\circ} \mathrm{C}$ and weighing; ash content was measured after ashing part of the filter for $4 \mathrm{~h}$ at $450^{\circ} \mathrm{C}$. The $\mathrm{C}$ and $\mathrm{N}$ contents of part of the filter were measured with a Carlo Erba atomic analyser. Another part of the filter was treated with persulphate and the $\mathrm{PO}_{4}$ content was measured by colorimetry. Faeces samples were measured similarly to SPM.

Chlorophyll a was measured after filtering $1 \mathrm{l}$ seawater over a Whatman GF/C filter, extraction in acetone, centrifugation and analysis by HPLC. The following conversions were assumed: Chlorophyll $\times 40=$ phyto-C (Bakker et al. 1994); molar C:N:P ratio of phytoplankton $=106: 16: 1$ (Redfield et al. 1963).

Seston data from a nearby routine field monitoring sampling site were used to calculate food availability in the field (Fig. 1). Food was expressed as POC, PON and POP concentration and phyto-C, phyto- $N$ and phyto-P concentrations, derived from converting measured chlorophyll a to C, N or P content. Seston concentration and composition are presented in Table 1.

Physiological rates and net budgets. Clearance rate was calculated as

$$
\mathrm{CR}=\left[\left(C_{\text {control }}^{\text {out }}-C_{\text {exp }}^{\text {out }}\right) / C_{\text {control }}^{\text {out }}\right] \times Q
$$

where $C R=$ clearance rate in $1 \mathrm{~h}^{-1}$ per mussel, $Q=$ flow rate in $1 \mathrm{~h}^{-1}$. $C_{\text {exp }}^{\text {out }}, C_{\text {control }}^{\text {out }}=$ concentration in total number of particles $\mathrm{ml}^{-1}$ at the outflow of the experimental and control chambers, respectively; 2 chambers without animals served as control for sedimentation, and correction for the control was done as follows:

$$
C_{\text {corrected }}^{\text {in }}=C_{\text {exp }}^{\text {in }}-\left(C_{\text {control }}^{\text {in }}-C_{\text {control }}^{\text {out }}\right)
$$

as $C_{\exp }^{\text {in }}$ is assumed to be similar to $C_{\text {control }}^{\text {in }}, C_{\text {corrected }}^{\text {in }}$ Can be considered to be similar to $C_{\text {control. }}^{\text {out }}$ As the residence time in the chambers was less than 6 min, the inflow 
Table 1. Seston concentration and composition during the experiments at the routine field monitoring station and in the field laboratory at the mouth of the Oosterschelde estuary. SPM, suspended particulate matter; POC: particulate organic carbon; PON: particulate organic nitrogen; POP: particulate organic phosphorus (all in $\mathrm{mg} \mathrm{l}^{-1}$ ); CHL: chlorophyll a in $\mu \mathrm{g} \mathrm{l} \mathrm{l}^{-1}$

\begin{tabular}{|c|c|c|c|c|c|c|c|c|c|c|}
\hline \multirow[t]{2}{*}{ Month } & \multicolumn{5}{|c|}{ Field monitoring station } & \multicolumn{5}{|c|}{ Field laboratory } \\
\hline & SPM & POC & PON & POP & $\mathrm{CHL}$ & SPM & POC & PON & POP & $\mathrm{CHL}$ \\
\hline May & 5.5 & 1.15 & 0.123 & 0.029 & 14.39 & 2.46 & 0.38 & 0.063 & 0.007 & 3.05 \\
\hline Jun & 6.4 & 0.73 & 0.08 & 0.019 & 3.5 & 3.36 & 0.47 & 0.068 & 0.01 & 1.38 \\
\hline Jul & 6.8 & 0.67 & 0.087 & 0.017 & 4.33 & 2.51 & 0.32 & 0.028 & 0.01 & 0.47 \\
\hline Aug & 4.6 & 0.53 & 0.061 & 0.012 & 5.07 & 3.7 & 0.23 & 0.028 & 0.01 & 0.26 \\
\hline Sep & 5.8 & 0.53 & 0.069 & 0.026 & 2.72 & 3.48 & 0.25 & 0.014 & 0.01 & 0.35 \\
\hline Oct & 16 & 0.98 & 0.026 & 0.025 & 1.14 & 3.41 & 0.3 & 0.018 & 0.007 & 0.18 \\
\hline Nov & 13 & 0.43 & 0.044 & 0.019 & 0.87 & 2.94 & 0.23 & 0.012 & 0.006 & 0.1 \\
\hline $\operatorname{Jan}$ & 6 & 0.5 & 0.025 & 0.009 & 0.79 & 7.05 & 0.68 & 0.03 & 0.01 & 0.86 \\
\hline Feb & 12.7 & 0.68 & 0.05 & 0.024 & 1.62 & 15.81 & 0.9 & 0.06 & 0.04 & 1.59 \\
\hline Mar & 21.5 & 1.48 & 0.103 & 0.036 & 4.87 & 18.36 & 1.3 & 0.077 & 0.02 & 3.9 \\
\hline Apr & 7.9 & 1.03 & 0.166 & 0.019 & 18.87 & 6.76 & 0.68 & 0.093 & 0.012 & 8.56 \\
\hline
\end{tabular}

( $C_{\text {control) }}^{\text {out }}$ was used as internal concentration (Widdows 1985, Smaal \& Widdows 1994).

Absorption efficiency (ae) was calculated according to the method of Conover (1966), but modified for the use of elements rather than organic matter (see Crisp 1984, Prins \& Smaal 1989), as

$$
\mathrm{ae}=1-(e / f)
$$

where $f$ = ratio elemental content/ash weight of food, and $e=$ ratio elemental content/ash weight of faeces

Respiration rate was calculated as

$$
\mathrm{RR}=\left\{\left(\left[\mathrm{O}_{2}\right]_{t_{0}}-\left[\mathrm{O}_{2}\right]_{t_{1}}\right) \times\left(V_{\text {chamber }}-V_{\text {mussel }}\right)\right\} /\left(t_{1}-t_{0}\right)
$$

where $\mathrm{RR}=$ rate of oxygen consumption in $\mu \mathrm{mol} \mathrm{O}_{2} \mathrm{~h}^{-1}$ per mussel, $\left[\mathrm{O}_{2}\right]=$ oxygen concentration at the start $\left(t_{0}\right)$ and at the end $\left(t_{1}\right)$ of the linear decline, $V=$ volume of chamber and mussel in 1 , and $t=$ time expressed in $h$. Oxygen consumption was converted to $C$ excretion based on a mean Respiratory Quotient $=0.85: 1 \mathrm{mg}$ $\mathrm{O}_{2}=0.32 \mathrm{mg} \mathrm{CO}$ (Hawkins \& Bayne 1985).

The excretion rate was calculated as

$$
E R=\left[\left(C_{\text {test }}-C_{\text {control }}\right) \times\left(V_{\text {chamber }}-V_{\text {mussel }}\right)\right] / t
$$

where $\mathrm{ER}=$ excretion rate in $\mu \mathrm{mol} \mathrm{NH}_{4}$ or $\mathrm{PO}_{4} \mathrm{~h}^{-1}$ per mussel, $C_{\text {test }}=$ concentration in experimental chamber and $C_{\text {control }}=$ concentration in control chamber, $\left(V_{\text {chamber }}-V_{\text {mussel }}\right)=$ volume of incubation seawater (1), and $t=$ incubation time (h).

The physiological rates of clearance, absorption, respiration and excretion can be integrated into budgets per element:

\section{Consumption $=$}

Production + Respiration + Excretion + Faeces

Production is total production of shell, tissue and gametes. For $C$, excretion is zero, while for $N$ and $P$, respiration is zero.
Scope for growth (SFG), defined as the difference between acquisition and expenditure (Warren \& Davis 1967, Smaal \& Widdows 1994), is similar to the Production term in the budget equation and can be calculated on the basis of the budgets. In this study, SFG of C, $\mathrm{N}$ or $\mathrm{P}$ was calculated as:

$\mathrm{SFG}\left(\mu \mathrm{g} \mathrm{h} \mathrm{h}^{-1}\right.$ mussel $)=$

$\mathrm{CR} \times$ food $\times$ ae - Respiration or Excretion

In this case respiration and excretion rates were expressed not on a molar basis, but in terms of weight.

Food consisted of the organic fraction of seston in the inflow of the grazing chambers, expressed as POC, PON, POP, or phyto-C, phyto-N, phyto-P. The SFG was also calculated with in situ food concentrations, based on seston, POC, PON, POP and chlorophyll a measurements obtained at the routine field monitoring sampling site (Table 1). No data were available for absorption efficiencies in July 1988 and January 1989, so average values for the season in question were used for budget calculation.

Net growth efficiency (NGE) is defined as SFG as a proportion of absorbed material, and calculated as

$$
\mathrm{NGE}=\mathrm{SFG} /(\mathrm{CR} \times \text { food } \times \text { ae })
$$

Elemental turnover is defined as the time needed to excrete an amount of an element equivalent to the amount contained in the tissue (Hatcher 1994), and calculated as

Elemental turnover $=$ tissue content / (respiration or excretion per day)

Growth rates. Growth rates were determined by comparing weight and composition (DFW, AFDW, C, $N, P$, glycogen content or molar stoichiometric ratios) of mussels at the start $\left(t_{0}\right)$ and at the end $\left(t_{x}\right)$ of the 1 mo period in the field laboratory, and expressing this as 
change in $\mu \mathrm{g} \mathrm{h}^{-1}$. Comparing mussels at 2 consecutive $t_{0}$ moments enabled the change in weight and composition in the field to be estimated. Weight was standardized for $50 \mathrm{~mm}$ mussels by monthly length/weight relationships. For comparing the growth of standard mussels throughout the year, it was assumed that growth rates were similar for mussels within a cohort with a shell length of 45 to $55 \mathrm{~mm}$. No data were available on $\mathrm{C}, \mathrm{N}$ and $\mathrm{P}$ content in January, so annual average values were used for the budget calculations for that month.

Growth in the field situation was predicted on the basis of SFG calculations assuming in situ phytoplankton-C, N or $\mathrm{P}$ as food; for each month the calculated SFG was added to the composition at the beginning of that month, and this was expressed as elemental weight change per mussel.

\section{RESULTS}

\section{Growth and composition}

The dry-flesh weight and ash-free dry weight of standard mussels $(50 \mathrm{~mm})$ in the Oosterschelde showed a clear seasonal pattern, with high values in summer and a decline in winter and spring Glycogen content increased in summer and fell from September to March (Fig 2a). The gonad index showed decreasing values in the period June to July 1988 and February to April 1989 (Table 2). This indicates that spawning occurred in the period March to June. The glycogen content was negatively correlated with the gonad index $(p<0.001)$.

The $C$ content of the mussels showed low values $(35 \%)$ in April and May, and values of about $40 \%$ for the rest of the year. The $\mathrm{N}$ content was lowest during
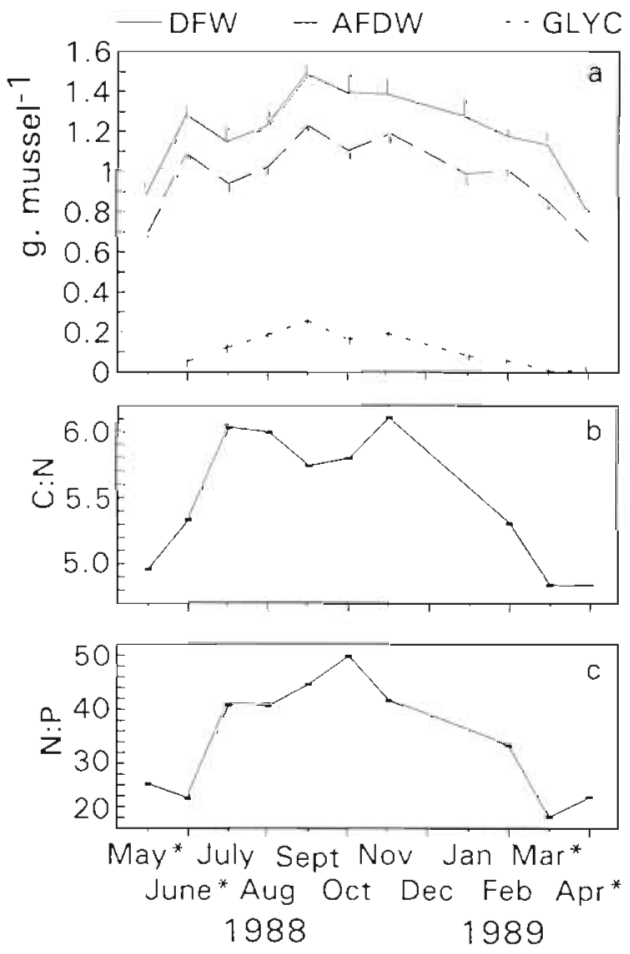

Fig. 2. Mytilus edulis. Seasonal changes in dry flesh weight (DFW), ash-free dry weight (AFDW) and glycogen content (GLYC) ( \pm SE in g), molar C:N and N:P ratio of standard mussels ( $5 \mathrm{~cm}$ length) in the Oosterschelde estuary from May 1988 to April 1989. *Spawning periods

summer $(7.5 \%)$ and was about $9 \%$ for the rest of the year. The $\mathrm{P}$ content was also lowest $(0.4 \%)$ in summer and autumn, but in winter and spring, values were in the range 0.7 to $1 \%$ of DFW (Table 2 ).

The C:N ratio of the mussels varied from 5 in March, April and May, to values of about 6 during the rest of the year (Fig. $2 \mathrm{~b}$ ). The N:P ratio was 20 to 25 in spring

Table 2. Mytilus edulis. Dry flesh weight (DFW), standard DFW of $50 \mathrm{~mm}$ mussels, organic shell weight (OSW), gonad index and tissue C, N and P content in \% of standaId DFW of mussels, sampled monthly on given dates from the Oosterschelde estuary

\begin{tabular}{|c|c|c|c|c|c|c|c|c|}
\hline Date & $\begin{array}{c}\text { Temperature } \\
\left({ }^{\circ} \mathrm{C}\right)\end{array}$ & $\begin{array}{l}\text { DFW } \\
\text { (g) }\end{array}$ & $\begin{array}{c}\text { DFW standard } \\
\text { (g) }\end{array}$ & $\begin{array}{l}\text { osw } \\
\text { (g) }\end{array}$ & $\begin{array}{l}\text { Gonad } \\
\text { index }\end{array}$ & $\% \mathrm{C}$ & $11 / 2 N$ & $\% \mathrm{P}$ \\
\hline 2 May 1988 & 13.5 & 0.71 & 0.881 & 0.32 & 233 & 36.02 & 8.45 & 0.69 \\
\hline 6 Jun 1988 & 16.1 & 1.17 & 1.274 & 0.33 & 3.30 & 42.84 & 9.37 & 0.85 \\
\hline 4 Jul 1988 & 16.7 & 1.07 & 1.143 & 0.31 & 1.60 & 39.71 & 7.67 & 0.40 \\
\hline $15 \mathrm{Aug} 1988$ & 18.2 & 1.20 & 1.22 & 0.33 & 1.20 & 39.98 & 7.77 & 0.41 \\
\hline 12 Sep 1988 & 16.1 & 1.44 & 1.48 & 043 & 0.90 & 42.08 & 8.54 & 0.41 \\
\hline 11 Oct 1988 & 13.2 & 1.40 & 1.39 & 0.36 & 1.70 & 43.00 & 8.64 & 0.37 \\
\hline 7 Nov 1988 & 9.5 & 1.36 & 1.38 & 0.36 & 1.50 & 41.13 & 7.84 & 0.40 \\
\hline 13 Jan 1989 & 5.1 & 127 & 1.264 & 0.37 & nd & nd & nd & nd \\
\hline 6 Feb 1989 & 6 & 1.17 & 1.174 & 0.34 & 4.10 & 42.25 & 9.28 & 0.60 \\
\hline 6 Mar 1989 & 7.5 & 1.04 & 1.129 & 0.34 & 3.70 & 40.02 & 9.64 & 1.02 \\
\hline 6 Apr 1989 & 8.5 & 0.77 & 0.8 & - & 2.90 & 35.10 & 8.46 & 0.76 \\
\hline Mean & & 1.15 & 1.19 & 0.35 & & 36.56 & 7.79 & 0.54 \\
\hline
\end{tabular}


and 40 to 50 during summer and autumn; in winter, values decreased again (Fig. 2c). Both ratios were low during the spawning period. Average annual C:N:P ratio was $173: 32: 1$.

\section{Physiological rates}

The clearance rates of the mussels varied throughout the year, with minimum values in autumn and spring and high values in summer and winter (Fig. 3a). There was no significant correlation between clearance rate and SPM ( $p=0.109)$ and chlorophyll $a(p=0.201)$ concentration, and a weak correlation with POC $(p=0.023$, $r^{2}=0.675, n=11$ ). Annual average clearance rate was $2.2 \mathrm{l} \mathrm{h}^{-1}$ for mussels with an average length of $50 \mathrm{~mm}$ and weight of $1.15 \mathrm{~g} \mathrm{DFW}$

The absorption efficiencies of $\mathrm{C}, \mathrm{N}$ and $\mathrm{P}$ fluctuated considerably throughout the year, with low values for all elements in October. Average annual absorption efficiencies did not show significant differences, and were $62.0,60.9$ and $61.4 \%$ for $\mathrm{C}, \mathrm{N}$ and $\mathrm{P}$ respectively (Table 3).

Respiration rates showed a seasonal pattern, with high values in early spring and summer, and relatively low values in autumn and winter (Fig. 3b). The seasonal pattern correlated significantly with the gonad index
Table 3. Mytilus edulis. Absorption efficiencies $(\%)$ of $\mathrm{C}$ (aepoc), $N\left(a e_{P O N}\right)$ and $P\left(a e_{P O P}\right)$ per month, with standard error (SE)

\begin{tabular}{|lcccccc|}
\hline Month & $\begin{array}{c}\text { aepoc } \\
\%\end{array}$ & SE & $\begin{array}{c}\text { ae pon } \\
\%\end{array}$ & SE & $\begin{array}{c}\text { ae pop } \\
\%\end{array}$ & SE \\
\hline May & 64.7 & 1.1 & 72.7 & 3.4 & 46.2 & 6.6 \\
Jun & 28.2 & 1.5 & 63.0 & 1.8 & 63.3 & 1.4 \\
Aug & 67.4 & 1.1 & 78.9 & 1.9 & 84.2 & 1.0 \\
Sep & 68.8 & 3.4 & 27.8 & 5.8 & 81.7 & 1.6 \\
Oct & 46.7 & 2.2 & 32.5 & 2.8 & 37.2 & 3.6 \\
Nov & 66.4 & 0.8 & 58.8 & 2.8 & 76.6 & 0.5 \\
Feb & 69.3 & 0.7 & 63.3 & 2.1 & 48.8 & 3.6 \\
Mar & 69.7 & 0.7 & 66.6 & 1.1 & 39.6 & 3.8 \\
Apr & 76.8 & 0.5 & 84.4 & 0.4 & 75.3 & 0.7 \\
Mean (SE) & 62.0 & $(4.5)$ & 60.9 & $(5.9)$ & 61.4 & $(7.3)$ \\
\hline
\end{tabular}

$(\mathrm{p}<0.001)$. Peak values were recorded in March 1989. There was some correspondence with clearance rates, but the convection requirements (respiration per unit clearance) varied considerably throughout the year.

Ammonia excretion peaked in spring and was low during the rest of the year (Fig. $3 \mathrm{c}$ ). The seasonal changes resembled respiration rates, but the main peak occurrcd latcr This was demonstrated by the C.N excretion ratio: low values, which occurred from May to July 1988 and in April 1989, indicated increased ammonia excretion relative to respiration, i.e. during and after the spawning periods (Fig 3e).
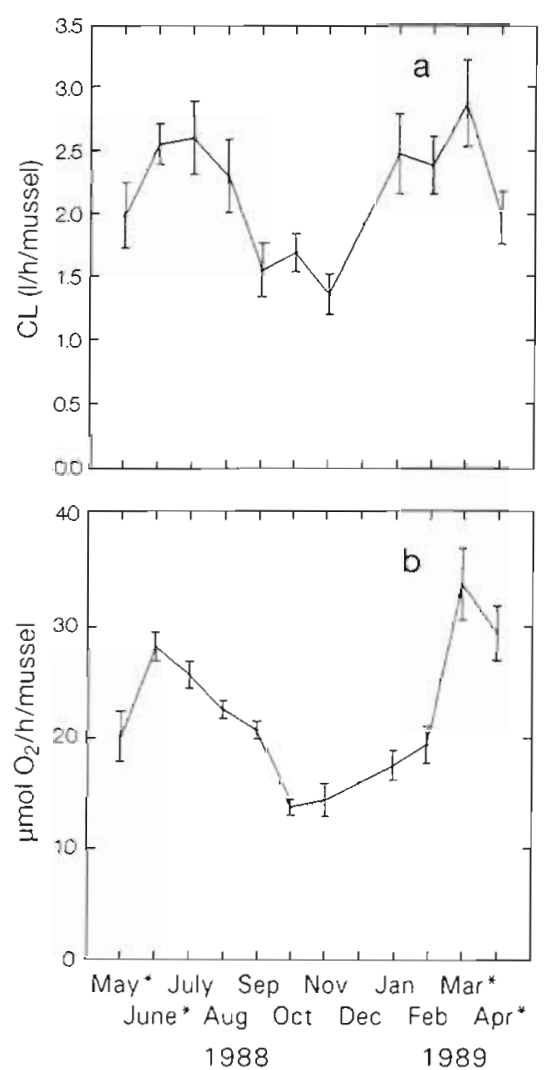
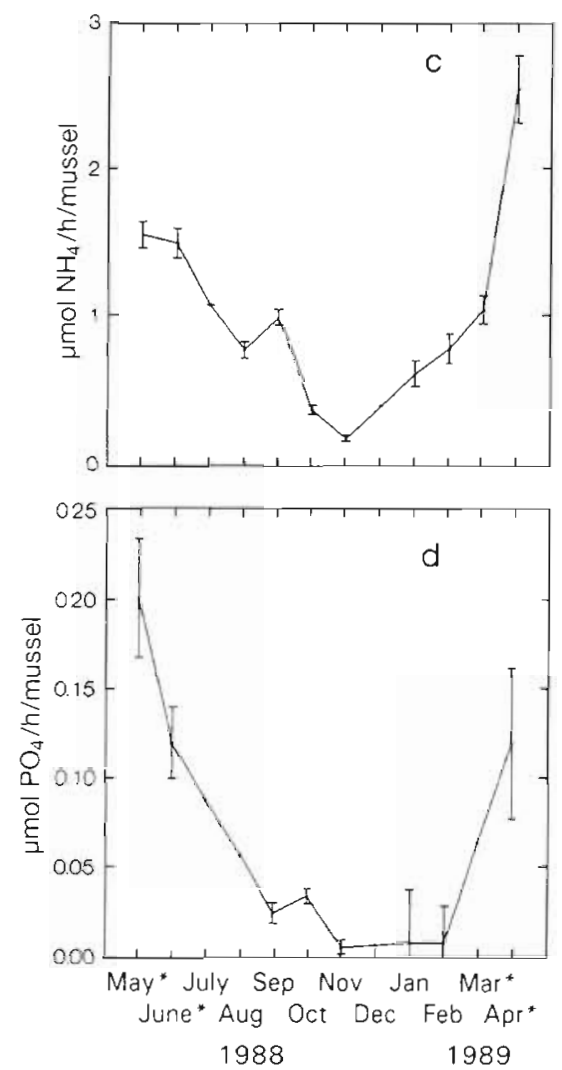
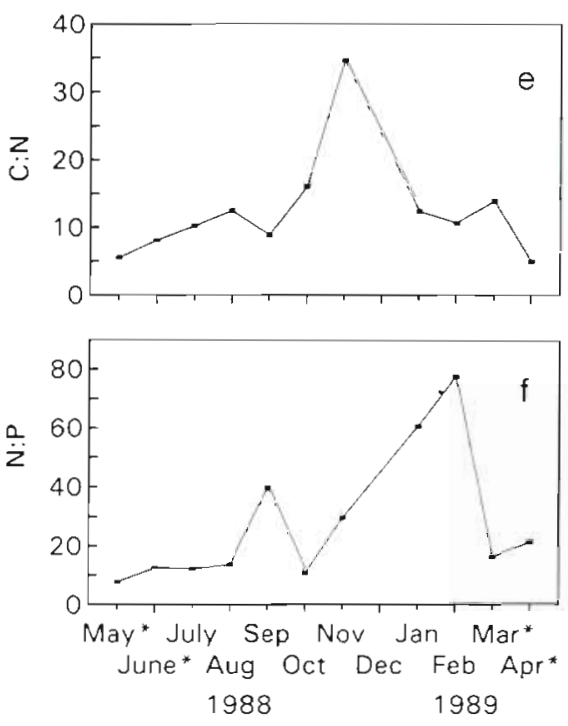

Fig. 3. Mytilus edulis. Seasonal changes in (a) clearance rate (volume swept clear in 1 musse $\mathrm{l}^{-\mathrm{i}} \mathrm{h}^{-1} \pm \mathrm{SE}$ ), (b) respiration rate ( $\pm \mathrm{SE}$ in $\mu \mathrm{mol} \mathrm{O} \mathrm{O}_{2} \mathrm{~h}^{-1}$ ), (c) $\mathrm{N}$ excretion rate ( $\pm \mathrm{SE}$ in $\mu \mathrm{mol} \mathrm{NH}_{4} \mathrm{~h}^{-1}$ ), (d) $\mathrm{P}$ excretion rate ( $\pm \mathrm{SE}$ in $\mu \mathrm{mol} \mathrm{PO}_{4}{ }^{3-} h^{-1}$ ), and (e) $\mathrm{C:N}$ and (f) N:P excretion ratios 
Phosphate excretion showed a clear seasonal pattern, and varied between $0.2 \mu \mathrm{mol} \mathrm{h} \mathrm{h}^{-1}$ in spring and $0.004 \mu \mathrm{mol} \mathrm{PO}_{4} \mathrm{~h}^{-1}$ in winter (Fig. $3 \mathrm{~d}$ ). The N:P excretion ratio showed values of around 10 in late spring, summer and October, and higher values, up to 80 in autumn and winter (Fig. 3f).

The carbon budget, based on the uptake of total POC, showed a positive SFG throughout the year; highest values were observed in winter and early spring (Fig. 4a). Net budgets with phyto-C as food showed positive SFG only in May 1988 and in March and April 1989 (Fig. 4b). The N and P budgets had similar annual variation (not shown). With PON and POP as food, the SFG was positive in most cases, while phyto- $\mathrm{N}$ and $-\mathrm{P}$ as food resulted in positive $\mathrm{SFG}$ only in May 1988 and March and April 1989.

\section{Scope for growth and growth}

\section{Experiments}

The calculated SFG was compared with measured elemental weight changes of the same mussels as used for the physiological measurements during their maintenance in the field laboratory for 1 mo. The measured C content of these mussels increased in May 1988 and in March 1989 and decreased in the other months; this is shown in Fig. 5 as (measured) net uptake and release rates respectively. The $\mathrm{N}$ content increased in February and March 1989, shown as net uptake, but the $P$
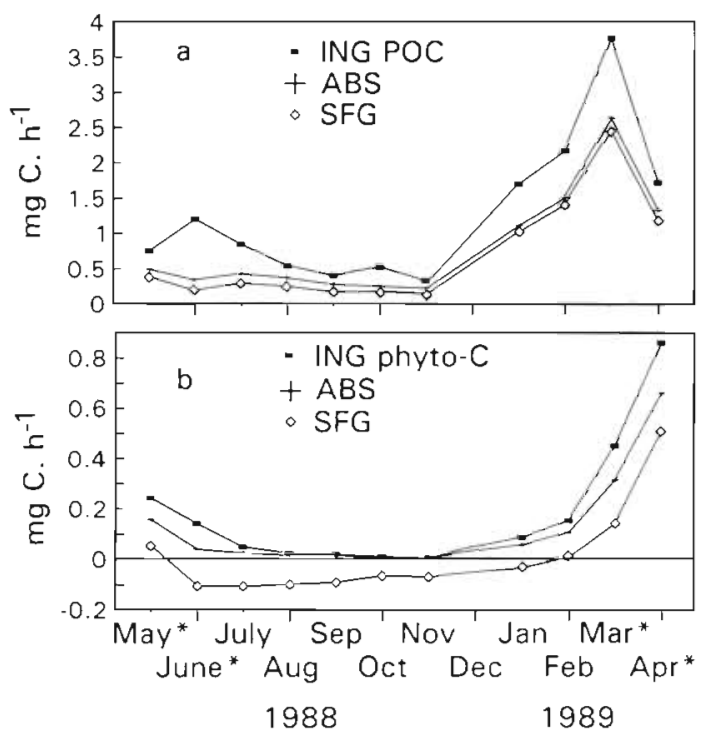

Fig. 4. Mytilus edulis. Ingestion (ING), absorption (ABS) and carbon scope for growth (SFG) in $\mathrm{mg} \mathrm{h}^{-1}$ of standard mussels, per month in the field laboratory, (a) with POC or (b) with phytoplankton-C as food. * Spawning periods content only increased in February 1989. In the other periods there was a net release of $\mathrm{N}$ and $\mathrm{P}$ per mussel (Fig. 5).

Based on total POC, PON or POP as food, predicted SFG (pred 1) was much higher than the observed growth rates (Fig. 5). The phyto-C SFG (pred 2) showed loss of $C$ from June to February, and net $C$ gain in March, April and May. The tissue C content showed comparable changes. The phyto-N SFG and the change in $\mathrm{N}$ content of the mussels were both positive in February and March 1989, and negative in the rest of the year in the period September to January, the measured $N$ loss of the mussels was larger than predicted. The phyto-P SFG and the changes in P content showed the same pattern, with a slight underestimation of growth rates in May, July and August; the difference was largest in February (Fig. 5).

From these results we conclude that phytoplanktonbased SFG gave a better prediction of tissue changes than estimates based on the $\mathrm{C}, \mathrm{N}$ and $\mathrm{P}$ composition of total organic material in seston.

\section{$\diamond$ pred1 $1+$ pred 2 - measured}

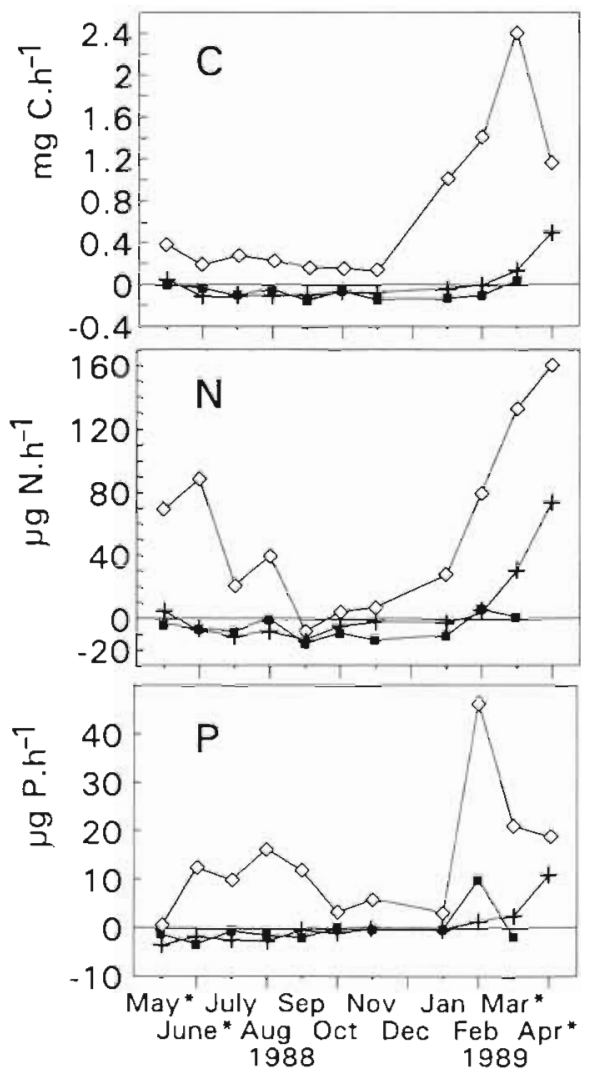

Fig. 5. Mytilus edulis. Uptake and release rates of $\mathrm{C}, \mathrm{N}$ and $\mathrm{P}$ as measured from differences in mussel tissue content during 1 mo in the field laboratory, and predicted from the net budgets with total organic matter (pred 1) and with phytoplankton (pred 2) as food. *Spawning periods 


\section{Field situation}

Comparison of growth and SFG was tested for the field situation, by predicting growth from net budgets with ambient phytoplankton as food source (Table 1), and comparing it with measured weight and composition changes of mussels from the field site. Observed and predicted growth were expressed as weight changes per month, and presented as an annual cycle (January to November), in order to better account for the spawning phase.

There was a good similarity between predicted and observed C content, except in March to June, when predicted growth exceeded observed growth. We attribute this to the occurrence of spawning in this period (Fig. 6). Also the nitrogen content of field mussels is compared with predicted values. It can be seen that the predicted values exceeded the observed values in the spawning period and in July. The mussels' actual phosphorus content and the predicted values were similar in winter; in autumn, the predicted values were higher, but their trend matched the trend in observed values. During the spawning period the predicted $\mathrm{P}$ content greatly exceeded the observed content (Fig. 6).
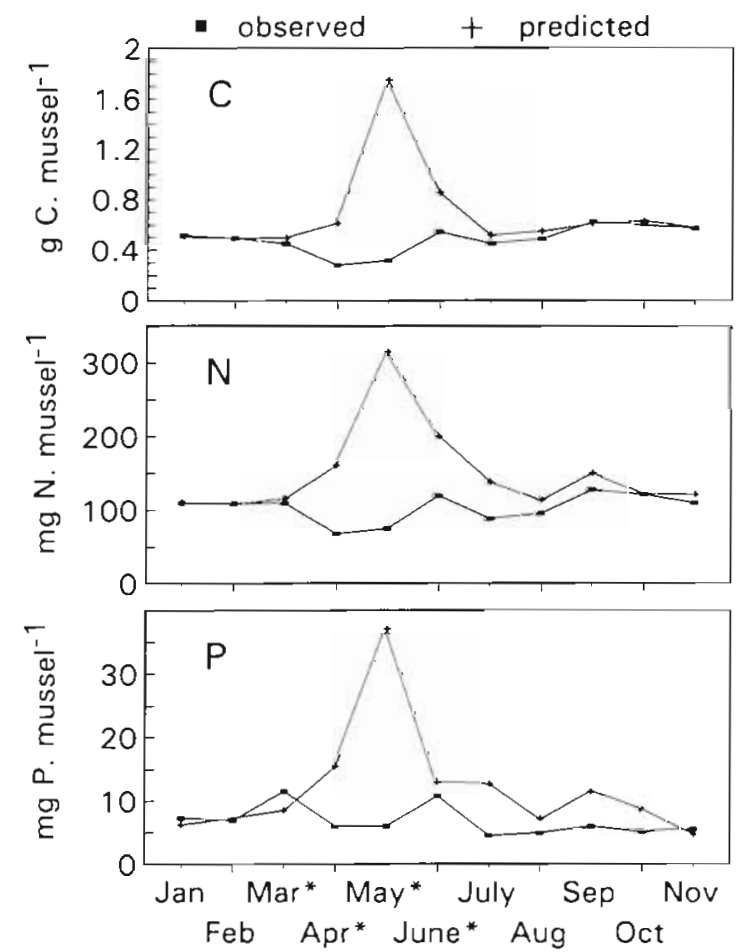

Fig. 6. Mytilus edulis. Tissue content of field mussels of $5 \mathrm{~cm}$ length for $C_{1} N$ and $P_{1}$ in comparison with predicted contents based on net budgets with phytoplankton as food, expressed per year * Spawning periods

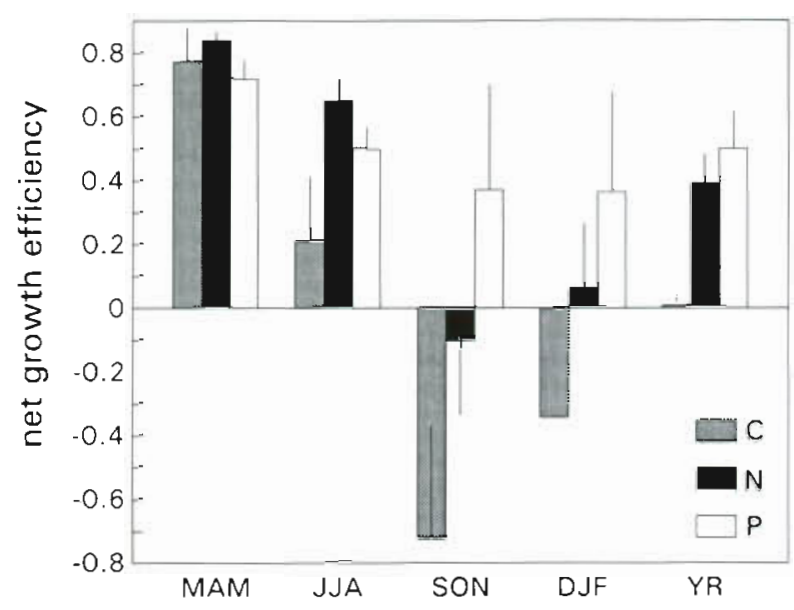

Fig. 7. Mytilus edulis. Net growth efficiency (NGE; with SE) based on ambient phytoplankton as food, per season. MAM: March, April, May; JJA: June, July, August; SON: September, October, November; DJF: December. January, February) and per year (YR) for $C, N$ and $P$

\section{Net growth efficiencies and elemental turnover}

NGE for $\mathrm{C}, \mathrm{N}$ and $\mathrm{P}$ with ambient phytoplankton as food were calculated per season, and for the whole period. As shown in Fig. 7 , they were negative for $C$ and $N$ in autumn and for $C$ also in winter. For $P$, NGE was always positive. The average annual NGE was high for $P$ and $N$ and almost zero for $C$. Differences were not significant in most cases, except for the average annual carbon NGE. This shows that a relatively large proportion of absorbed $\mathrm{P}$ and $\mathrm{N}$ was available for growth, whereas carbon is accumulated in spring and summer and lost in autumn and winter.

The turnover time per element, relative to tissue content, in spring and summer was relatively short: loss of elements was relatively great in comparison with tissue content (Table 4). In autumn and winter the turnover time was longer, particularly for $\mathrm{N}$ and $\mathrm{P}$. On an annual basis, $\mathrm{N}$ turnover was slower than $\mathrm{P}$ and $\mathrm{C}$ turnover.

Table 4. Mytilus edulis. Turnover time per element (d) per season and per year, with standard error (SE)

\begin{tabular}{|lccl|}
\hline & C & N & \multicolumn{1}{c|}{ P } \\
\hline Mar, Apr, May & $92(8)$ & $155(56)$ & $107(51)$ \\
Jun, Jul, Aug & $151(9)$ & $269(38)$ & $101(14)$ \\
Sep, Oct, Nov & $304(28)$ & $1050(343)$ & $561(244)$ \\
Dec, Jan, Feb & $222(9)$ & $456(27)$ & $937(24)$ \\
Year & $189(25)$ & $485(137)$ & $380(114)$ \\
\hline
\end{tabular}



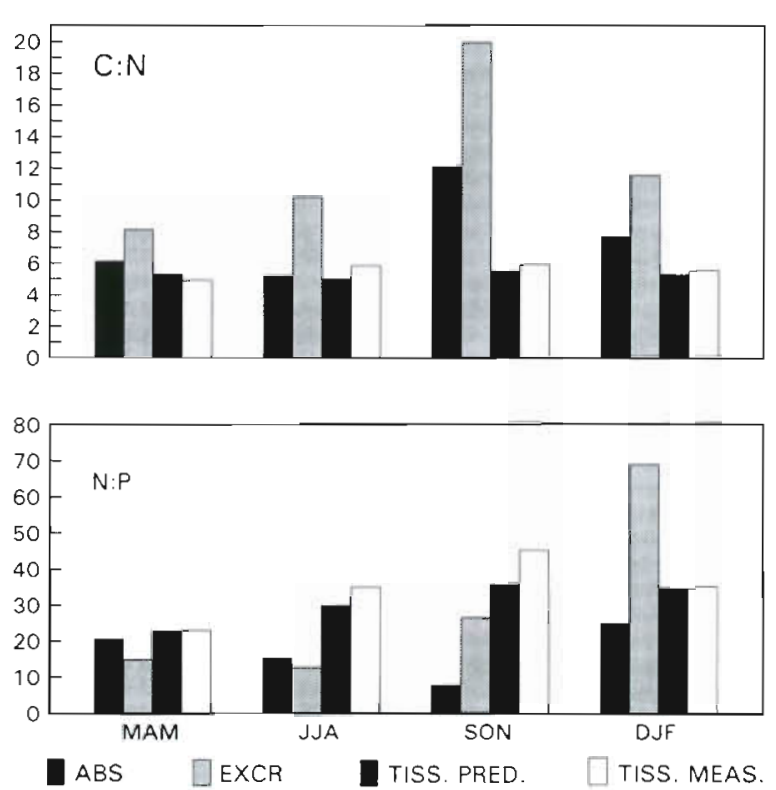

Fig. 8. Mytilus edulis. Seasonal changes of C:N and N:P ratios of absorption, excretion, predicted and measured tissue content of field mussels per season (see legend of Fig. 7)

\section{Stoichiometric comparisons}

C:N ratio

The C: N ratio of excretion was lowest in spring (Fig. 8), when the $\mathrm{N}$ excretion rates were high (see Fig. $3 \mathrm{c}$ ), and peaked in autumn. The excretion ratios were always higher than the absorbed $\mathrm{C}: \mathrm{N}$ ratios, which indicates net accumulation of $\mathrm{N}$ over $\mathrm{C}$. The latter is confirmed by the predicted tissue $\mathrm{C}: \mathrm{N}$ ratios, which were lower than absorption and excretion ratios, and also lower than the phytoplankton-Redfield ratio, resulting in accumulation of $\mathrm{N}$. The predicted ratios were very similar to the observed tissue ratios. Tissue $\mathrm{C}: \mathrm{N}$ ratio was low in spring, due to a low $C$ content of the mussels (Table 2), which corresponded with a low glycogen content (Fig, 2).

\section{N:P ratio}

Comparison of the N:P absorption with excretion ratios showed that $N$ accumulated more than $P$ in spring and summer (Fig. 8). The N:P excretion ratio was relatively low in that period. In autumn, the N:P absorption ratio was low, while the N:P excretion ratio was high, indicating that $\mathrm{P}$ was accumulating more than $N$. Yet the reverse was indicated by the predictions: the predicted N:P tissue ratio was relatively high in autumn and the observed tissue ratio was even higher. The fact that the tissue ratios always exceeded the absorbed ratios and the phytoplankton-Redfield ratio provided further evidence for $\mathrm{N}$ accumulation. exceeding $\mathrm{P}$ accumulation.

\section{DISCUSSION}

Seasonal changes in weight and tissue composition of mussels in temperate zones generally show a pattern of increase in glycogen content in late spring and summer, and a decrease in autumn and winter to minimum values in the spawning period. Protein content also increases in spring and summer, but decrease later than glycogen. These patterns have been observed in locations such as the Conwy estuary, Wales, UK (Dare \& Edwards 1975), Dutch Wadden Sea (Pieters et al. 1979, 1980), Killary Harbour, Ireland (Rodhouse et al. 1984a, b) and Whitsand Bay, England (Hawkins et al. 1985). The latter authors also demonstrated correspondence between biochemical (protein) and elemental $(\mathrm{N})$ tissue composition. We too found that the dry weight and glycogen content of $5 \mathrm{~cm}$ mussels increased from May to September and then declined. It seems probable that the dry weight losses we measured in March and June were associated with 2 spawning peaks (see Hummel et al. 1989). Weight decrease of mussels in autumn and winter is a normal phenomenon in temperate zones, and is attributed to food scarcity (see Pieters et al. 1979).

The tissue $C: N$ ratio revealed that $C$ content was relatively high in summer, but bottomed out in winter, concomitantly with the glycogen content. The tissue $\mathrm{C}: \mathrm{N}$ ratios we found are similar to observations on seasonal variation reported by Rodhouse et al. (1984b) and Hawkins et al. (1985), but are higher than the C:N ratio of 3.85 presented by Vink \& Atkinson (1985). The $\mathrm{N}: \mathrm{P}$ ratio we found had a similar pattern, with relatively low N values in winter. Vink \& Atkinson (1985) observed an N:P ratio of 58 ; the annual average tissue $\mathrm{N}$ :P ratio we measured was 32 . We found the P content showed more pronounced seasonality than $N$ content, with relatively low values in summer and high values in spring. The only comparable study we know of is one by Kuenzler (1961), in which the seasonal variation in $\mathrm{P}$ content of Modiolus demissus in a Georgia (USA) salt marsh is reported to be between 0.45 and $0.65 \%$ for individuals of $1 \mathrm{~g}$ DFW, with maxima during the spawning period.

Ingestion and absorption of food showed a clear seasonal pattern. The lower clearance rates in spring might be an effect of Phaeocystis blooms (Prins et al. 1994, Smaal \& Twisk 1997), which occurred in May 1988 and April 1989 in the western part of the Oosterschelde estuary (Bakker et al. 1994). In autumn, when food concentrations were at a minimum, relatively low 
clearance rates were observed. Bayne (1993) has clearly shown that, under conditions of food scarcity, mussels may show a seasonal shift in feeding and digestion potential, towards reduced investment in food acquisition (see also Hawkins et al. 1985). In research related to the study reported here, Smaal et al. (in press) did not find any seasonality in clearance rates, but the animals in their experiment were kept in natural seawater and given additional food. We therefore conclude that low clearance rates in autumn might be a response to low food concentrations

Absorption efficiencies fluctuated greatly over the year. The lowest values for absorption efficiencies, particularly nitrogen, were found in the period of food scarcity. However, whereas Hawkins et al. (1985) and Hawkins \& Bayne (1985) observed that mussels fed with Phaeodactylum tricornutum displayed a clear seasonal pattern in absorption efficiencies of $\mathrm{C}, \mathrm{N}$ or $\mathrm{P}$, we found no such pattern.

The seasonal pattern of respiration obviously reflected the reproductive cycle. Others have also been able to correlate respiration rate with gametogenic cycle (Bayne \& Widdows 1978, Hawkins et al. 1985, Smaal et al. in press). Bayne \& Widdows (1978), Hawkins et al. (1985) and Kreeger et al. (1995) reported ammonium excretion rates comparable to those we found, with high values in periods when glycogen reserves were depleted.

Kuenzler (1961) reported an average phosphate excretion rate of $0.086 \mu \mathrm{mol} \mathrm{P}-\mathrm{PO}_{4} \mathrm{~g}^{-1} \mathrm{~h}^{-1}$ for Modiolus demissus, while for Mytilus edulis, Kautsky \& Wallentinus (1980) reported rates from 0.01 to $0.77 \mu \mathrm{mol} \mathrm{g}^{-1}$ $h^{-1}$ in February and August, and Asmus et al. (1994) measured phosphate excretion rates in mussels ranging from $0.07 \mu \mathrm{mol} \mathrm{g}^{-1} \mathrm{~h}^{-1}$ in September to $0.17 \mu \mathrm{mol}$ $\mathrm{g}^{-1} \mathrm{~h}^{-1}$ in May. Vink \& Atkinson (1985) reported excretion rates of $0.016 \mu \mathrm{mol} \mathrm{P}_{-} \mathrm{PO}_{4} \mathrm{~g}^{-1} \mathrm{~h}^{-1}$, but also additional organic $\mathrm{P}$ loss of up to $40 \%$ of inorganic $\mathrm{P}$ excretion. Their total $\mathrm{P}$ excretion rates, however, were relatively low. We measured rates from 0.004 to $0.20 \mu \mathrm{mol} \mathrm{P}-\mathrm{PO}_{4}$ mussel ${ }^{-1} \mathrm{~h}^{-1}$; the maximum rates agree well with those previously reported in the literature, but the excretion rates in winter may have been underestimated. This might be due to adsorption of dissolved $\mathrm{P}_{-} \mathrm{PO}_{4}$ into the faeces produced during the P excretion measurements (Balzer et al. 1983).

Low C:N excretion ratios in spring, similar to the phenomenon we found, have previously been described by Bayne \& Scullard (1977), Bayne \& Widdows (1978) and Hawkins et al. (1985), expressed as O:N ratio. According to Gabbott (1983) protein is being exploited as an internal energy source in spring, because glycogen reserves had bottomed out in early winter As a result, nitrogen excretion increases relative to respiration.
Calculated SFG for the field situation was based on ambient food concentrations and physiological rates measured in the laboratory. Prins et al. (1996) found that clearance rates measured in situ in the Oosterschelde estuary were reasonably similar to laboratory measurements. In our experiments, seston concentration and composition were in the same range in the laboratory and the field situation (Table 1). Prins \& Smaal (1989) found no correlation between clearance rate and SPM concentrations in the range 2 to $50 \mathrm{mg}$ $\mathrm{l}^{-1}$. Similarly, Bayne et al. (1993) found no correlation between clearance rate and SPM concentrations between 1 and $10.3 \mathrm{mg} \mathrm{l}^{-1}$, nor did they find a correlation between absorption efficiency and SPM concentration. Therefore, we believe that our laboratory-derived physiological rates could be extrapolated to the field situation. Since no data on selective ingestion were available, we implicitly assumed a high selection efficiency of organic malerial when SPM concentration exceeded the pseudofaeces threshold of $5 \mathrm{mg} \mathrm{I}^{-1}$ (Bayne \& Newell 1983).

Budgets of $\mathrm{C}, \mathrm{N}$ and $\mathrm{P}$ with total POC, PON or POP as food shorved a rolatively high scope for growth per element, both for the laboratory and for the field situation. This cannot have been due to enhanced absorption efficiencies, because these were comparable with reported values for natural food particles (Bayne \& Newell 1983). Our comparison of SFG based on total organic matter with measured changes in tissue content and with SFG based on phytoplankton as food suggests that food availability was less than total organic matter concentration would suggest.

A possible explanation for the difference between phytoplankton-based and total organic matter-based SFG under the conditions of low SPM prevailing in laboratory experiments could be that the organic content of seston was measured using all particles $>1.2 \mu \mathrm{m}$, whereas mussels of $5 \mathrm{~cm}$ only retain particles $>4 \mu \mathrm{m}$ efficiently (Møhlenberg \& Riisgård 1978). A considerable amount of the organic material in seston consists of the smallest particles, which are not available as food (Kautsky \& Evans 1987). Therefore, phytoplankton, which is generally $>4 \mu \mathrm{m}$ in the Oosterschelde estuary (Bakker et al. 1994), can be considered as a better indicator of food availability than organic matter. The amount of phytoplankton-C in total POC varied over the year, from $2 \%$ in November to $50 \%$ in April (see Table 1). Except during the spawning period, phytoplankton-based SFG calculations and observed tissue content were very similar throughout the year, both for the field and for the laboratory situation.

A further explanation for the difference between predicted tissue content of field mussels based on total organic matter as food and measured growth, might be our assumption that mussels select phytoplankton 
more efficiently than detritus. Indeed, Prins et al. (1996) have shown that phytoplankton was retained more efficiently by a mussel bed than POC. The similarity we found between measured growth and phytoplankton-based scope for SFG supports this hypothesis.

Bayne \& Worrall (1980) compared growth of mussels from Lynher and Cattewater (2 estuarine sites near Plymouth, UK) with calculated SFG and found good similarity, particularly for the Lynher population. In that case, food consisted of POM, at concentrations from 1 to $5 \mathrm{mg} \mathrm{l}^{-1}$, which was absorbed with an efficiency of only $34 \%$ on average (Bayne \& Widdows 1978). They did not present any data on SPM concentration in their paper. Clausen \& Riisgård (1996) compared the laboratory and field growth of small mussels, and for both conditions showed that specific growth rates were a function of the phytoplankton concentrations. Given these findings and those reported in the preceding paragraphs, we conclude that phytoplankton can be considered as the main food source of the mussels.

We did not measure the allocation of elements in shell and byssus threads, but they are (by definition) incorporated in the scope for growth calculations. Total organic shell growth, however, was of limited importance in comparison with tissue weight changes (Table 2). Hawkins \& Bayne (1985) report byssal thread secretion of $2.86 \mu \mathrm{g} \mathrm{C}$ and $0.75 \mu \mathrm{g} \mathrm{N}$ per h for 45 to $57 \mathrm{~mm}$ mussels, which is low compared to the growth rates of -100 to $+25 \mu \mathrm{g} \mathrm{Ch}^{-1}$ and -10 to $+10 \mu \mathrm{g}$ $\mathrm{N} \mathrm{h}^{-1}$ we measured.

During spawning, calculated tissue content based on SFG was much higher than observed tissue content, particularly for carbon. Bayne (1984) estimated fecundity (loss of gametes) of mussels of various size classes from different areas, observing considerable variation in fecundity, with a maximum loss of $20 \%$ body weight to spawning for mussels of $1 \mathrm{~g}$ DFW. A similar fecundity figure was reported by Rodhouse et al. (1985). Pieters et al. (1980), however, observed much larger weight changes of mussels during spawning; up to $50 \%$ in Wadden Sea mussels in April. Kautsky (1982) also observed weight losses of this magnitude due to spawning. Rodhouse et al. (1984a) reported weight loss up to $30 \%$ due to spawning in late summer. Similar values were presented by Thompson (1979). It seems probable that spawning loss not only consists of the loss of gametes, but also of losses due to cell damage of reproductive tissue and loss of dissolved organic material. This could explain the large difference we found between SFG and tissue content during spawning: integrated over the spawning period, the difference between SFG and growth was $2132 \mathrm{mg} \mathrm{C}, 285 \mathrm{mg} \mathrm{N}$ and $43 \mathrm{mg} \mathrm{P}$; loss ratios were 8.7 for $\mathrm{C}: \mathrm{N}$ and 14.7 for $\mathrm{N}: \mathrm{P}$. Rodhouse et al. (1984b) give a $\mathrm{C}: \mathrm{N}$ ratio of 3.19 for spermatozoa and 4.34 for eggs. These ratios are lower than our calculated $C: N$ loss ratios, suggesting that there was additional loss, particularly of $C$

Average annual NGE with ambient phytoplankton as food were positive for $\mathrm{P}$ and $\mathrm{N}$ and approximately zero for $C$. The negative growth efficiencies we found in autumn and winter can be attributed to food scarcity, as excretion rates were relatively low in this period. Hawkins \& Bayne (1985) also showed higher net growth efficiencies for $\mathrm{N}$ than for $\mathrm{C}$. They observed a clear seasonal pattern, with negative efficiencies for both $\mathrm{C}$ and $\mathrm{N}$ in winter (March) and for $\mathrm{C}$ in autumn (October), and concluded that their mussel populations were likely to be limited by carbon. In contrast, Grant \& Cranford (1991) observed higher C than N net growth coefficients of Placopecten magellanicus fed phytoplankton. They compared SFG with actual growth and observed that energy-based scope for growth overestimated observed growth. Poor quality food sources with a higher C:N ratio (aged kelp) or a high inorganic content (sediment) gave lower growth rates and corresponded better with SFG. They concluded that energy or carbon-based SFG overestimated growth under nitrogen-limited conditions. Kreeger et al. (1995) demonstrated excretion of the carbon fraction of amino acids which were hydrolysed and transaminated for biosynthesis of proteins, and suggested that mussels were more likely to have been nutritionally limited by their quantitative amino- $N$ requirements rather than by their energy demand. In our study, seasonal NGE for $\mathrm{P}$ was always positive and, on average, was higher than for $\mathrm{N}$. However, possible underestimation of $\mathrm{P}$ excretion in winter might account for the high NGE for P. A high NGE indicates that a relatively small fraction of the absorbed material is used for maintenance, and a relatively large fraction is available for growth and reproduction. Our observations show that the mussels use relatively more $\mathrm{N}$ and $\mathrm{P}$ than $\mathrm{C}$ for growth and reproduction.

Hatcher (1994) analysed the turnover time of $N$ and $P$ in benthic marine invertebrates, defined as the time needed to excrete an amount of an element equivalent to the amount contained in the body. There was a higher turnover of $\mathrm{P}$ than of $\mathrm{N}$ in most species. $\mathrm{P}$ turnover correlated with tissue $\mathrm{P}$ content, and seemed not to be regulated in response to fluctuations in food supply. This is in contrast to $\mathrm{N}$ turnover and protein sparing, as described by Hawkins \& Bayne (1985). We calculated the average annual turnover times of $\mathrm{C}, \mathrm{N}$ and $P$ as 189,485 and 380 d respectively, which shows, in contrast to Hatcher (1994), that nitrogen was retained better than $\mathrm{P}$ and $\mathrm{C}$.

Comparison of tissue ratios with absorbed ratios shows that nitrogen was accumulated over carbon. This was achieved by adjustment of the $C$ and $N$ excre- 
tion rates, reflected in the higher C: $\mathrm{N}$ excretion than absorbed ratios, which consequently result in lower $\mathrm{C}: \mathrm{N}$ ratios of the SFG. Except for the spawning period, the predicted and observed tissue $\mathrm{C}: \mathrm{N}$ ratios were quite similar.

The low N:P absorption ratio in autumn is attributable to low absorption efficiency of $\mathrm{N}$ in this period. High N:P excretion ratios in autumn and winter were related to low $\mathrm{P}$ excretion rates. The predicted tissue $\mathrm{N}$ :P ratio in autumn was relatively high and not consistent with evidence for the accumulation of $\mathrm{P}$ demonstrated by the absorption and excretion ratios. SFG based on $\mathrm{P}$ was higher than observed growth in that period, possibly because $P$ excretion was underestimated. Predicted tissue ratios agreed well with observed tissue ratios. The fact that tissue $\mathrm{N}: \mathrm{P}$ ratios (average $\mathrm{N}: \mathrm{P}=32$ ) were higher than ratios of food $(\mathrm{N}: \mathrm{P}=16)$ and absorption indicates that nitrogen was actively retained over phosphorus.

In conclusion, our study showed that food availability, acquisition and metabolic requirements were different for C, N and P. Quantification of $C, N$ and $P$ budgets and calculation of SFG provided a tool for predicting the elemental composition of mussels in the field, when phytoplankton was considered as the main food source. Although the NGE based on $\mathrm{P}$ was higher than based on $\mathrm{N}$, the turnover of $\mathrm{N}$ was slower than for $\mathrm{P}$ and $\mathrm{C}$. It is therefore concluded that nitrogen was retained more effectively than $C$ and $P$. In phytoplankton the C:N ratio of phytoplankton was generally higher and the N:P ratio was lower than in mussel tissue, which implies that $N$ availability in food is relatively limited. As absorption efficiencies were similar for $\mathrm{C}, \mathrm{N}$ and $\mathrm{P}$, we infer that effective $\mathrm{N}$ retention was achieved by efficient $\mathrm{N}$ metabolism.

Acknowledgements. The authors are grateful to D. I. Zandee for his advice during the experiments, to B. L. Bayne, I C. Prins and $\mathrm{W}$. J. Wolff for valuable suggestions for improving the manuscript and to J. Burrough-Boenisch for correcting the English text.

\section{LITERATURE CITED}

Asmus H, Asmus RM, Zubillaga GF (1994) Do mussel beds intensify the phosphorus exchange between sediment and tidal waters? Ophelia 41:37-55

Bakker C, Herman PMJ, Vink M (1994) A new trend in the development of the phytoplankton in the Oosterschelde (SW Netherlands) during and after the construction of a storm-surge barrier. Hydrobiologia 282/283:79-100

Balzer W, Grasshoff K, Dieckmann P, Haardt $H_{1}$ Petersohn U (1983) Redox-turnover at the sediment/water interface studied in a large bell jar system. Oceanol Acta 6: $337-344$

Bayne BL (1984) Aspects of reproductive behaviour within species of bivalve molluscs. In: Engels W (ed) Advances in invertebrate reproduction 3. Elsevier Science Publishers, New York, p 357-366

Bayne BL (1993) Feeding physiology of bivalves: time dependence and compensation for changes in food availability. In: Dame RF (ed) Bivalve filter feeders in estuarine and coastal ecosystem processes. NATO ASI Series G Vol 33, p 1-24

Bayne BL, Bubel A, Gabbott PA, Livingstone DR, Lowe DM, Moore MN (1982) Glycogen utilisation and gametogenesis in Mytilus edulis L. Mar Biol Lett 3:89-105

Bayne BL, Iglesias JIP, Hawkins AJS, Navarro E, Héral M, Deslous-Paoli JM (1993) Feeding behaviour of the mussel, Mytilus edulis: responses to variations in quantity and organic content of the seston. J Mar Biol Assoc UK 73:813-829

Bayne BL, Newell RC (1983) Physiological energetics of marine molluscs. In: Saleuddin ASM, Wilbur KM (eds) The Mollusca, Vol 4, Physiology part I. Academic Press, New York, p 407-515

Bayne BL, Scullard C (1977) Rates of nitrogen excretion by species of Mytilus (Bivalvia: Mollusca). J Mar Biol Assoc UK 57:355-369

Bayne BL, Widdows $J$ (1978) The physiological ecology of two populations of Mytilus edulis L. Oecologia 37:137-162

Bayne BL, Worrall CM (1980) Growth and production of mussels Mytilus edulis from two populations. Mar Ecol Prog Ser 3:317-328

Berg JA, Newell RIE (1986) Temporal and spatial variations in the composition of seston available to the suspension feeder Crassostrea vircinica. Estuar Coast Shelf Sci 23: 375-386

Bergmeyer C (1966) Methoden der enzymatischen Analysen. Springer-Verlag, Berlin

Cactée GC (1982) Tidal and seasonal variation in particulate and dissolved organic carbon in the western Dutch Wadden Sea and Marsdiep tidal inlet. Neth J Sea Res 15: $228-249$

Clausen I, Riisgård HU (1996) Growth, filtration and respiration in the mussel Mytilus edulis: no evidence for physiological regulation of the filter-pump to nutritional needs. Mar Ecol Prog Ser 141:37-45

Conover RJ (1966) Assimilation of organic matter by zooplankton. Limnol Oceanogr 11:338-354

Crisp DJ (1984) Energy flow measurements. In: Holme NA, McIntyre AD (eds) Methods for the study of the marine benthos. Blackwell Scientific Publications, Oxford, p 284-373

Dare PJ, Edwards DB (1975) Seasonal changes in flesh weight and biochemical composition of mussels (Mytilus edulis L.) in the Conwy estuary, North Wales. J Exp Mar Biol Ecol 18:89-97

Gabbott PA (1983) Developmental and seasonal activities in marine molluscs. In: Hochachka PW (ed) The Mollusca, Vol 2. Environmental biochemistry and physiology 2. Academic Press, New York, p 165-217

Grant $\mathfrak{J}$, Cranford PJ (1991) Carbon and nitrogen scope for growth as a function of diet in the sea scallop Placopecten magellanicus. J Mar Biol Assoc UK 71:437-450

Grasshoff W, Ehrhardt Mr Kremling K (1983) Methods of seawater analysis, 2nd edn. Verlag Chemie, Weinheim

Hatcher A (1994) Nitrogen and phosphorus turnover in some benthic marine invertebrates: implications for the use of C:N ratios to assess food quality. Mar Biol 121:161-166

Hawkins AJS (1985) Relationships between the synthesis and breakdown of protein, dietary absorption and turnovers of nitrogen and carbon in the blue mussel, Mytilus edulis $\mathrm{L}$. Oecologia 66:42-49

Hawkins AJS, Bayne BL (1985) Seasonal variation in the relative utilization of carbon and nitrogen by the mussel 
Mytilus edulis: budgets, conversion efficiencies and maintenance requirements. Mar Ecol Prog Ser 25:181-188

Hawkins A.JS, Bayne BL (1992) Physiological interrelations, and the regulation of production. In: Gosling $E$ (ed) The mussel Mytilus: ecology, physiology, genetics and culture. Elsevier, Amsterdam, p 171-212

Hawkins AJS, Salkeld PN, Bayne BL, Gnanger E, Lowe DM (1985) Feeding and resource allocation in the mussel Mytilus edulis: evidence for time-averaged optimization. Mar Ecol Prog Ser 20:273-287

Hawkins AJS, Smith RFM, Bayne BL, Héral M (1996) Novel observations underlying fast growth of suspensionfeeding shellfish in turbid environments: Mytilus edulis. Mar Ecol Prog Ser 131:179-190

Hummel H, Fortuin AW, Bogaards RH, de Wolf L, Meyboom A (1989) Changes in Mytilus edulis in relation to shortterm disturbances of the tide. In: Klekowski RZ, Stycynska-Jurewicz E. Falkowski L (eds) Proc 21st Eur Mar Biol Symp. Ossolineum, Gdansk, p $77-89$

Kautsky N (1982) Quantitative studies on gonad cycle, fecundity, reproductive output and recruitment in a Baltic Mytilus edulis population. Mar Biol 68:143-160

Kautsky N, Evans S (1987) Role of biodeposition by Mytilus edulis in the circulation of matter and nutrients in a Baltic coastal ecosystem. Mar Ecol Prog Ser 38:201-212

Kautsky N, Wallentinus I (1980) Nutrient release from a Baltic Mytilus-red algal community and its role in benthic and pelagic productivity. Ophelia, Suppl 1:17-30

Kreeger DA, Hawkins AJS, Bayne BL, Lowe DM (1995) Seasonal variation in the relative utilization of dietary protein for energy and biosynthesis by the mussel Mytilus edulis. Mar Ecol Prog Ser 126:177-184

Kuenzler EJ (1961) Phosphorus budget of a mussel population. Limnol Oceanogr 6:400-415

Mohlenberg F, Riisgård HU (1978) Efficiency of particle retention in 13 species of suspension feeding bivalves. Ophelia 17:236-246

Nienhuis PH, Smaal AC (1994) The Oosterschelde estuary (The Netherlands): a case study of a changing ecosystem. Kluwer Acad Publ, Dordrecht

Pieters H, Kluytmans JH, Zandee DI, Cadée GC (1980) Tissue composition and reproduction of Mytilus edulis in relation to food availability. Neth J Sea Res 14:349-391

Pieters H, Kluytmans JH, Zurburg W, Zandee DI (1979) The influence of seasonal changes on energy metabolism in Mytilus edulis (L). I. Growth rate and biochemical composition in relation to environmental parameters and spawning. In: Naylor E, Hartnoll RG (eds) Cyclic phenomena in marine plants and animals. Pergamon Press, Oxford, p 285-292

Prins TC, Dankers N, Smaal AC (1994) Seasonal variation in the filtration rates of a semi-natural mussel bed in relation to seston composition. J Exp Mar Biol Ecol 176:69-86

Prins TC, Smaal AC (1989) Carbon and nitrogen budgets of the mussel Mytilus edulis and the cockle Cerastoderma edule in relation to food quality. Scientia Marina 53:477-482

This article was submitted to the editor
Prins TC, Smaal AC (1994) The role of the blue mussel Mytilus edulis in the cycling of nutrients in the Oosterschelde estuary (The Netherlands). Hydrobiologia 282/283:413-429

Prins TC, Smaal AC, Dankers N, Pouwer AJ (1996) Filtration and resuspension of particulate matter and phytoplankton on an intertidal mussel bed in the Oosterschelde estuary (SW Netherlands). Mar Ecol Prog Ser 142:121-134

Redfield AC, Ketchum BH, Richards FA (1963) The influence of organisms on the composition of seawater. In: Hill NM (ed) The sea, Vol 2. Wiley-Interscience, New York, p 26-77

Rodhouse PG, Roden CM, Burnell GM, Hensey MP, MCMahon T, Ottway B, Ryan TH (1984a) Food resource, gametogenesis and growth of Mytilus edulis on the shore and in suspended culture: Killary Harbour, Ireland. J Mar Biol Assoc UK 64:513-529

Rodhouse PG, Roden CM, Hensey MP, Ryan TH (1985) Production of mussels, Mytilus edulis, in suspended culture and estimates of carbon and nitrogen flow: Killary Harbour, Ireland. J Mar Biol Assoc UK 65:55-68

Rodhouse PG, Roden CM, Ryan TH (1984b) Resource allocation in Mytilus edulis on the shore and in suspended cuiture. Mar Biol 84:27-34

Seed R, Brown RA (1977) A comparison of the reproductive cycles of Modiolus (L.), Cerastoderma (= Cardium) edule (L.), and Mytilus edulis (L.) in Strangford Lough, Northern Ireland. Oecologia 30:173-188

Smaal AC, Haas HA (in press) Seston dynamics and food availability on mussel and cockle beds. Estuar Coast Shelf Sci

Smaal AC, Twisk F (1997) Filtration and digestion of Phaeocystis sp. by the mussel Mytilus edulis L. J Exp Mar Biol Ecol 209:33-46

Smaal AC, Vonck APMA, Bakker M (in press) Seasonal variation in physiological energetics of Mytilus edulis L. and Cerastoderma edule L. of different size classes. J Mar Biol Assoc UK

Smaal AC, Widdows J (1994) The scope for growth of bivalves as an integrated response parameter in biological monitoring. In: Kramer K (ed) Biomonitoring of coastal waters and estuaries. CRC Press, Boca Raton, p 247-268

Thompson RJ (1979) Fecundity and reproductive effort in the blue mussel (Mytilus edulis), the sea urchin (Strongylocentrus droebachiensis) and the snow crab (Chionoecetes opilio) from populations of Nova Scotia and Newfoundland. J Fish Res Bd Can 36:955-964

Vink S, Atkinson MJ (1985) High dissolved C:P excretion ratios for large benthic marine invertebrates. Mar Ecol Prog Ser 21:191-195

Warren CE, Davis GE (1967) Laboratory studies on the feeding bioenergetics and growth in fish. In: Gerking SD (ed) The biologic basis of freshwater fish production. Blackwell Scientific Puclications, Oxford, p 175-214

Widdows J (1985) Physiological measurements and procedures. In: Bayne BL, Brown DA, Burns $K$, Dixon D, Ivanovici $D$, Livingstone DR, Lowe DM, Moore MN, Stebbing ARD, Widdows J (eds) The effects of stress and pollution on marine animals. Preager, New York, p 3-45

Manuscript first received: December 9, 1996

Revised version accepted: May 5, 1997 